\title{
WHO GETS ON YOUR NERVES?
}

\author{
GÁBOR KIRÁLY $Y^{l}$
}

Franks, David D. (2010) Neurosociology. The Nexus between Neuroscience and Social Psychology. New York: Springer. pp. 216

As almost all sociologists I developed by training a deeply seated allergic reaction to any biological explanations of social issues. The typical line of causation, which Lakatos calls biological imperialism in his paper on biology and sociology (LaKatos, 2008, p. 157), claims to have found rock hard evidence of this or that be it is the biologically given nature of gender roles, IQ differences of races, altruistic behavior among people sharing the same genes and so on. Also in popular thinking there is too much 'naturalization' going on about our intrinsic human nature for my liking. Being natural is something which everybody should strive for nowadays as if there is an independent yardstick of naturalness and as if what is generally considered the very core of being human would not be historically and culturally context dependent.

However, this is just one side of the story since by teaching social theory I am also aware of the fact how difficult it is for social theorists to deal with issues such as the body, the embodiment of knowledge, unconscious or semi-conscious strategies and the topic of intersubjectivity (SHILling, 2001; Crossley, 2005). Also in micro sociological terms, in face-to-face contexts we do not react to each other as disembodied agents with intentions and interests but constantly 'read' the faces of others and interpret more or less subtle signs of bodily gestures (ROGERS, 2003, p. 106-114). It also should be mentioned that sociology has a long history of intimate relationship with biology as numerous 'sociological' concepts show it such as social morphology, function, systems and the environment, interpenetration, autopoesis and so on (PÁL, 2001, 2004; BALOGH \& KARÁCSONY, 2000, pp. 269-295).

1 Gábor Király is senior lecturer at the Budapest Business School; e-mail: kiraly.gabor@pszfb. bgf.hu 
So, when I found Franks' book titled Neurosociology I was quite interested as to whether this book is another reductionist attempt to simplify complex social processes into straightforward biological principles, or alternatively, it is a way to 'bring the body back' into social scientific thinking. As a matter of fact, Franks is aware of some sociologists' biased attitudes towards such matters, so he starts with distancing his approach from reductionist biological explanations. The basis of his approach lies in social neuroscience, a new special subfield of neuroscience, which attempts to understand the biological processes of the body in terms of their role in social interactions and cooperation.

Franks intends to integrate the findings of this new socially oriented field of neuroscience into sociology in general and symbolic interactionism in particular. The main argument goes that our brain is inherently social in both its evolution and its functioning. In this review I will first give an overview of the evolution of social brain hypothesis and then I will move on to the functioning of this concept focusing on topics related to intersubjectivity. In the last section, I will attempt to delineate a few tentative possibilities of convergences between sociology and social neuroscience following the lead in Franks' book.

\section{THE EVOLUTION OF THE SOCIAL BRAIN}

One of the main questions concerning the evolution of the human brain is about the source of human intelligence. There is a popular narrative characterizing both the scientific and the lay thinking claiming that our intelligence evolved through our tool-making practices thereby adapting to the harsh conditions of our environment. However, there is an alternative explanation which gradually gains acceptance among neuroscientist. The argument is that if we want to understand the complexity of human thought we need to go beyond the depths of the individual brain. Therefore, the origins of human intelligence must be in external conditions of social life.

Our ancestors having been driven out of forests (perhaps by the climate) to savannahs might have developed the necessary practical intelligence and emotional control to establish and live in a complex network of cooperation with fellow members of their species. Very intelligent but separate individuals, however sophisticated their tools were, would have been far more vulnerable than organized groups defending themselves and hunting or foraging together.

According to this line of argument, the other important factor greatly influencing our general intelligence was group size. There is a clear 
relationship between intelligence, brain size and the number of members in the group in the animal kingdom. The greater the number of like individuals with whom an animal deals on a routine basis, the more intelligent it is since it needs more elaborate cognitive capacities to identify and track changes in the 'social current'. As Christakis and Fowler (2010, p. 267) pointed out in their book about social networks titled Connected, primates were the first type of species which started a close knit connection and cooperative relationship not only with their mating partners but also same sex individuals. ${ }^{2}$ Just like in a networking site such as Facebook, relationships with new 'significant others' open the possibility of new relationships. If one relationship has been established, it is very likely that an individual gets to know the friends of his or her friend as well. The argument is that to keep track of social life with all its drama and entangled relationships we, and of course our close relatives the other primates, needed to develop a far more effective cognitive system. But why is it difficult to manage a larger group $?^{3}$ The answer lies in the fact that the more members are in the group, the more complex social living becomes. Blackburn point this out in relation to moral dilemmas represented in art but also in soap operas:

"Drama, literature, and poetry all work out ideas of standards of behaviour and their consequences. This is overtly so in great art. But it shows itself just as unmistakably in our relentless appetite for gossip and the confession shows and the soap opera. Should Arlene tell Charlene that Rod knows that Tod kissed Darlene, although nobody has told Marlene? Is it required by loyalty to Charlene or would it be a betrayal of Darlene? Watch on (BLACKBURN, 2009, p. 4-5)."

Of course, our ancestors also needed to survive in harsh conditions so toolmaking and intelligence must also be in close relationship. Yet, the emerging consensus is that social intelligence was the first on the scene and made tool production possible. Tool-making presupposes self-conscious control of our biological impulses. This control could only have developed through the requirement of living together and cooperating, in other words, its source is in the social environment. Using Franks' own words:

2 The original argument is from Robin Dunbar and Susanne Shultz primatologists (2007).

3 Did we really need to develop new cognitive capacities when the group size went up let's say from five to ten? There is only one possible relationship between two people, three between three, six between four and ten between five. The number of potential relationships increases exponentially with group size (CHRISTAKIS \& FowLER, 2010, p. 267) 
"Current thinking is that the pressure to select for intelligence came from the demands of the social organization. Especially important was the advantage given to those who could anticipate the reactions of others and foresee the consequences of their social actions. (...) The real 'engine in our evolution', they say, was the signaling of affect which underpins a sense of shared reality - what sociologists see as 'intersubjectivity' (FRANKS, 2010, p. 31)."

The development of language is also reconsidered in the light of the above mentioned arguments. It is common knowledge that the "evolution of Homo sapiens' brain is integrally tied to a pressing need to communicate, which developed over millions of years into spoken language" (FrANKs, 2010, p. 32). Social neuroscience's position is that the brain's organization and language were not developed for the purpose of rational decision-making. Instead, it developed in order to enhance human connectivity, to put it differently, language, first and foremost, is about maintaining group coherence and not a way of analyzing facts of the environment better.

What is the precursor of language then? In primate behavior, group coherence is maintained and strengthened in the practice of grooming. If a member of a chimpanzee group loses its partner for example, it starts to groom others in the group more thereby strengthening other ties to deal with the loss. What about humans? As Christakis and Fowler asks should you "groom your friends, or just talk to them?" (2010, p. 276)?

From an evolutionary point of view, language is far more efficient than grooming. We can only groom one friend, colleague, student or professor at a time while we can speak to a lot of them at the same time (although in a conversation there are also limits in the size of the circle we can maintain effective communication with). This means that language allows for larger and more complex social structure. Imagine a university, or any institution for that matter, where social relationships are maintained by grooming. We would spend most of our time grooming and not working too much. ${ }^{4}$ Instead of paying too much attention of what tasty little thingies lie under our fellow group members' hair we speak to them. All in all, in this regard, language's primary function is about social cohesion:

"Whereas chimps spend 20\% of their time grooming each other, humans spend $20 \%$ of their time in social interaction, mostly in

\footnotetext{
4 However, the fact that we do not groom, not in public spaces at least, does not mean automatically that we spend more time with work. Anecdotal evidence shows that time spent with work might be in negative relationship with frequent language use.
} 
conversation, much of which is about each other. Two-thirds of human conversation pertains not to technological problems or rational decision-making, but to gossip about other people (FRANKS, 2010, p. 30)."

Language then is a much more efficient alternative to achieve the necessary social cohesion in a large group. There is a positive feedback loop here between group size, cognitive capacity and social sensitivity. While in the past, group size was determined by the time necessary for grooming, with the appearance of language the size of a community was no longer constrained by this factor. This is also critical to the development of further cognitive capacity.

With language use community size went up, which caused further development in cognitive capabilities and social sensitivity necessary to deal with the larger number of people in the social network. According to this perspective, the large human brain evolved not to solve relatively simple problems associated with tool use but to deal with the complexities posed by social living (i.e. see above the dilemma of Marlene, Charlene and Arlene). Moreover, most of the time we use our brain specifically for that purpose as the next section will point that out.

\section{THE FUNCTIONING OF THE SOCIAL BRAIN}

\section{Development of the social brain}

Our brain is also inherently social in its functioning in everyday life. First and foremost, it is social because it needs other brains to develop to a fully functional brain. However nice Kipling's story about Mowgli may be, no child raised by wolfs, or any other animal for that matter, will be human in the sense that he or she will not be able to interact fully and share a common reality with others. A $21^{\text {st }}$ century version of the feral child's story is Danielle's case. Danielle is a little American girl who was raised in darkness and isolation till age 7 when she was found by the police. ${ }^{5}$ Since she passed the age when

5 I found Danielle story in a magazine in my sisters' temporarily empty flat when I 'fled' there from my inquisitive little daughter to work on this review. The interesting thing was that this magazine was there for 2 years but I have never once realized that it might be interesting. Yet, when I read about the nature and development of the social brain suddenly I 'discovered' that it was there all along. My previous and present actions made it possible for me to discover that article. This is what the author, following the ideas of the pragmatists like Dewey and Mead, calls the primacy of action in perception. While the original behaviorist understanding of the relationship between perception and action is subsequential (stimulus $\rightarrow$ conscious thought 
human relationships are established, she shows the same symptoms as autistic children. ${ }^{6}$ So our brain can only develop and maintain its full capacity in a social context. In relation with this, Franks quotes Leslie Brothers, the first neuroscientist focusing exclusively on the social nature of the brain:

"...while our individual brains are singular and self-contained, the processes on which they depend for functioning are social ones. We have seen that there is no fully working human brain without the presences of other brains. The functioning brain is social in the sense that any given brain is completely dependent on other brains for its development. Without question, the synaptic brain is contained in our individual skulls but the intangible thought processes which these synapses make possible depend on a social environment with other actors who are engaged in everyday public discourse and interaction (BROTHERS quoted by FRANKS, 2010, p. 38)."

To live in a social environment, to cooperate with others we need a common world to live in and act upon, in other words, we need a sense of shared reality. ${ }^{7}$ This 'intersubjectivity', the connection between separate brains is one of the most interesting research field of social neuroscience not only in the phases of development but also in contexts of everyday life. Below, I will present Franks' account on mirror neurons and the question of intersubjectivity and then the review move on to the topics of language and metaphors again.

\footnotetext{
$\rightarrow$ response [action]), the pragmatist gave primacy to the action. This means that we perceive the world according to our actions and tasks at hand. Using Franks own words: "Perception becomes a selective assessment of what action possibilities an object affords for our intentions. All perception is selective and it is our actions that select the relevant from the irrelevant in any particular context. The world is not known by passive camera-like imprints or images or representations of how it 'actually is.' It is known by the human actions which it makes possible ([emphasis in the original] Franks, 2010, p. 87)."
}

6 Danielle's case is a well-documented, shocking but at the same time moving story. For those who are interested there is an excellent documentary site with interviews at http://www. tampabay.com/specials/2008/reports/danielle/ (retrieved 12/08/2011). Danielle was adopted and now lives in a loving and trusting environment. She has developed significantly not shying away from human contact and touch anymore but it is dubious whether she will be able to use language at all.

7 Christakis and Fowler calls humans ,ultrasocial” animal and this is also true for our perception (2010, p. 265). There is significant evidence that our color vision also developed in order to be able to identify color changes in each other's face signifying emotional changes. Our social life not only influenced how we think, how we make decisions in the present about the future but was also altered to some extent the way we perceive the world (ibid. 266-267). 


\section{Intersubjectivity}

Franks starts out his explanation on intersubjectivity by asking what a society would look like if we were all individualist empiricists. We might think that the source of our knowledge is basically direct observation. Traditional empirical epistemological thinking, argues the author, is highly compatible with individualistic societies with their asocial focus on the private. 'Seeing is believing' the saying goes while sociologists, social psychologists and behavioral economists all stress the point that quite often it is the other way around (Berger \& Luckmann, 1966; Aronson, 2008; Rogers, 2003; Thaler \& Sunstein, 2008; Ariely, 2008, 2010). Common beliefs, stereotypes often affect more how we perceive the world than our direct experience. As Franks put it about empiricism:

"Originally empiricism relied on fact, seen as in opposition to theory, and fact was gathered by the individual's private senses. But to one person standing on a hill, the shape of a tree may look very different from that observed by a person up close to it. The problem with this is if we rely purely on observation, there would have to be two trees. That would be what pure observation gives in this case. If the empirical 'world of appearance' to the individual alone is all we accept, then the two persons are isolated from each other in their two different perceptual worlds (FRANKS, 2010, p. 40)."

However, in all historical and cultural contexts people presupposed the existence of a common world. We cannot see two trees but we see one since we abstract the idea of the tree out of our sensory experience. We are also able to share the tree with others around us by talking about it. The belief that the tree is the same (regardless of our perspective in space and regardless of the lighting conditions by day or by night) shows our deeply seated need for believing in a common world. And the belief in the common world, writes Franks, is the sine quo-non of human connection and society itself (p. 40).

Even if we all have differences about how we see the world, be these differences political, religious or scientific, we appeal to settle our differences in this presumably shared world abstracted from individual sensory experience. As Franks puts it "without the assumption of one common tree, discussants would have nothing to argue over (emphasis in the original, $\mathrm{p}$. 40-41)." Disagreement must be over the same subject matter or we would talk past each other without understanding each other at all. In theory, there would be no problem since everybody could retreat to his or her private world and cut or climb his or her own trees. Yet, in reality we are quite aware that if one 
wants to cut the tree and the other wants to climb the tree there would be a conflict of interest between the parties involved as environmentalists' actions like tree sitting highlight this point.

We act upon the same world and we instinctively know this. Without this instinctive knowledge society, social life and social action could not exist. Intersubjectivity is then essential for human discourse and communication. In social scientific literature it is a truism that we share the world through linguistic communication. Language is the means through which we construct our reality and the social phenomenon of linguistic communication can explain both the universality of 'intersubjectivity' and the enormous variance of the realities constructed in different historical and cultural contexts (Schutz, [1932] 1967; Berger \& Luckmann, 1966; Foucault [1969] 1972). So, according to Franks,...

"...the conclusion to the above is that the assumption of the common world arises out of human talk. This in turn is the answer to Simmel's question of what makes society possible. We become part of each other through intersubjectivity and symbolic discourse (FRANKS, 2010, p. 41)."

However, argues Franks, the fact that intersubjectivity is necessary for human conversation does not mean that it is caused by human conversation at the same time. This would be a tautological argument. However, a cause must always precede an event. According to Franks, the key to this enigma can be found in our neural wiring. Intersubjectivity is literally built into our bodies and can be explained by the human brain's mirror neurons and our tendencies to imitate others. In the next section I will attempt to explain what mirror neurons are and how they contribute to our understanding of others.

\section{Mirror neurons and intersubjectivity}

To support this reasoning, it is necessary to explain the function of a vital cell type of the brain in terms of the somatic background of intersubjectivity. These are the mirror neurons. The 'mirror' part in the expression explains a lot about their function implying that it has to do with others' actions. The Society for Neuroscience introduces the topic as follows:

"You see a stranger stub her toe and you immediately flinch in sympathy. You watch a baseball outfielder run to catch a long fly ball and feel your heart racing and your leg muscles pumping 
along with him. You notice a friend wrinkle up his face in disgust while tasting some food and suddenly your own stomach recoils at the thought of eating. This ability to instinctively and immediately understand what other people are experiencing has long baffled neuroscientists, psychologists, and philosophers alike. Recent research now suggests a fascinating explanation: brain cells called mirror neurons (SFN, 2008, p. 1).'

So mirror neurons are a special type of brain cell which have to do with imitation, empathy and understanding others. These special brain cells are a set of neurons discovered in the 1990's in the premotor cortex of macaque monkeys ${ }^{8}$. On one occasion a researcher was reaching for his food, when he noticed that certain neurons started to fire in one of the monkeys' brain. This area was exactly the same which became activated when the animal was making a similar hand movement ( $\mathrm{SFN}_{\mathrm{F}}$ 2008). After this initial discovery extensive research was made about mirror neurons not only in other primates but also in humans.

As Christian Keysers explains to us in an interview, what these special neurons show us is that we have mechanisms, in other words brain circuits, "transforming the sight of someone else's action into the motor program that we would use to perform the same action (KEYSERS, web)". In order to elucidate this complex system for lay people, he gives the example of drinking saying that if we see someone take a glass of cold water and drink it on a hot summer day, we not only see her drink it, but we literally feel it in our body how good it would be to drink one ourselves. ${ }^{9}$

Coming back to the social scientific vocabulary, the existence and function of mirror neurons would prove that perception is a not a passive process of registering images of objects in the space around us. Perception and action are deeply interwoven since we are actually doing, in other words, reenacting in the motor cortex what we are watching. That also means that understanding involves much more than merely understanding symbols.

8 Premotor cortex is understood to be the brain part through which we control parts of our bodies in voluntary movements.

9 I cannot help having the suspicion that this process might be a bit trickier in the everyday messiness of social situations. Consider, for example, a simple social interaction: a boxing match. One is hitting the other and the other is being hit. In such a situation, what is happening to our mirror neurons, in other words, how do we perceive these actions with our motor cortex? Who do we identify with and whose actions do we model in our brain? To understand this situation one might have to draw upon social factors like preferences, stereotypes and groupbelonging. This is even more valid when more actors are involved in social interactions. 
Schutz' illustration of how we understand others revisits Weber's famous example of a man cutting wood. If we want to know what this man is doing we have to make an interpretative leap meaning that we have to put ourselves in his place. We can do this by drawing on our past experience. While doing this we use language and other meaningful signs which make the whole process easier. These signs are collectively shared resources acting as a source of bridge between minds (Schutz [1932] 1967; CALhoun et al., 2007. p. 28). They allow us to connect our own experience to that of others.

Mirror neurons help us to understand the woodcutter not only at a symbolic level but also through our motor system. We match his observed movements with the axe with to the movements we ourselves could perform. Using the arguments of social neuroscientists, Franks highlights the fact that without a mirror neuron system we would still be able to make sensory depictions of others' behavior. However, it would be much more difficult to know their intentions and to understand what they were really doing. Through our own motor competencies we can shortcut all the time-consuming deliberations about their possible intentions, expectations, and motivations. ${ }^{10}$ This system allows us to make judgments about others' behavior immediately and accurately without necessary language use and without deliberate cognition. Using Franks' words:

"Human society is made possible through this process.(...) Mirror neurons enable us to go further than observation of movements into a realm of understanding these movements, namely because on a preobjective level they are our movements too, and are laced with similar intentions. This is different from Mead's solution to the problem of intersubjectivity and human connection. His role-taking was completely linguistic being focused on significant symbols and the self-conscious control of behavior (FRANKS, 2010, p. 89)."

All in all, we do not only understand others through the mediation of language, signs and cognition but immediately and directly through our

10 The article on the homepage of Society for Neuroscience writes about this in the following way: „Before the discovery of mirror neurons, scientists generally believed that our brains use logical thought processes to interpret and predict other people's actions. Now, however, many have come to believe that we understand others not by thinking, but by feeling. For mirror neurons appear to let us 'simulate' not just other people's actions, but the intentions and emotions behind those actions. When you see someone smile, for example, your mirror neurons for smiling fire up, too, creating a sensation in your own mind of the feeling associated with smiling. You don't have to think about what the other person intends by smiling. You experience the meaning immediately and effortlessly ( $\mathrm{SFN}, 2008$, p. 1).” 
bodies. On the Society for Neuroscience's webpage about mirror neurons there is experimental evidence shown that observing the same action, such as grasping a cup, in different contexts elicits different levels of mirror neuron activity. Our mirror neuron system responds differently if we see someone grasp a cup in order to drink or to clean it. This finding demonstrates that our mirror neuron system not only codes the observed action ("that's a grasp") but it also identifies the intention behind the action ("that's a grasp to drink" or "that's a grasp to clear the table") (SFN, 2008, p. 2).

\section{Metaphors and language}

Even if we can understand others on a preverbal level without conscious thought and the use of language that does not mean that language would operate on a separate level detached from our bodies and from bodily movements. Neuroscience research demonstrates that language use and thinking using linguistic symbols is deeply intertwined with our bodies in several ways.

One aspect of this is what is called the 'motor theory of speech perception'. This intimidating expression means that when we hear others speak we do not actually hear the sounds directly through our ears but we indirectly understand the meaning of the sounds by activating those parts of the motor cortex which are responsible for tongue movements, that is, "through making the same speech movements ourselves in the motor cortex (FrANKS, 2010, p. 96)". In other words, we do not record sounds per se with our ears but we speak them to ourselves unconsciously in the motor cortex. As Franks puts it: listening to one talking also means doing the talk (p. 97).

This conclusion resulted from evidence found among war veterans who lost their sights. Mechanical devices were developed for them to transform written texts into sounds. It turned out that it is extremely hard for them to understand the text read aloud by a machine since they cannot translate the sounds with their bodies through their brain. ${ }^{11}$

Moreover, other studies show that understanding words associated with the movement of a particular body part such as "lick, kick, or pick are simulated in those respective parts of the primary motor cortex that activate respective

11 Other studies showed that listening to words with a more accentuated sound resulted more tension in the tongue muscles. We say the words for ourselves with closed mouth. This also underpins the argument of psychologists and sociologists such as Vygostky and Mead that thinking is an internalized dialogue, or to put it differently, thinking can be viewed as speaking without uttering the words loudly. 
movement in the tongue, feet, or fingers (Franks, 2010, p. 92)." That means that we use the same brain areas to move a particular body part and to understand words and expressions related to that body part.

Another aspect of language's close relationship with the body is the frequent use of metaphors in all known languages. According to the author, metaphors contribute towards understanding intersubjectivity since many of our metaphors refer to experiences with our bodies and to its motor actions affecting the world. 'Getting out' of a project, being 'hit' with the news, 'reaching' a goal and 'grasping' the meaning of these expressions are all examples of this phenomenon.

All of us know what these expressions mean because we know the meanings of the verbs 'getting out', hit', 'reach' and 'grasp'. We do these actions with our bodies and we also know how it feels to be 'hit', be 'grasped', 'reached' or stay alone in a car after everyone 'got out'. If we use the expression 'take the blows in a debate', it 'carries' meaning through connecting concrete experience of our bodies to abstract notions. Referring the meaning back to the body gives sense to metaphors and makes the intersubjective meaning accessible to all who have already experienced what we refer to.

Neuroscientists also used an old technique called the bouba/kiki test to illustrate this point. If people are asked which is called bouba and which is kiki in the diagram below, most will say bouba is the jaggy one, while kiki is the one with sharp edges. This is because, irrespective of the respondents native language, we all connect the sharp sounds to pointed, jaggy images while we connect soft sounds with rounded, curved visualizations. The fact that this response of participants seems to transcend language, and most of the people tested answered in the same way, represent universal and automatic tendencies of the human brain towards sense-making by metaphors (p. 5356). 
DIAGRAM 1. (RAMACHANDRAN \& HUBBARD, 2001, p. 19) $)^{12}$ :
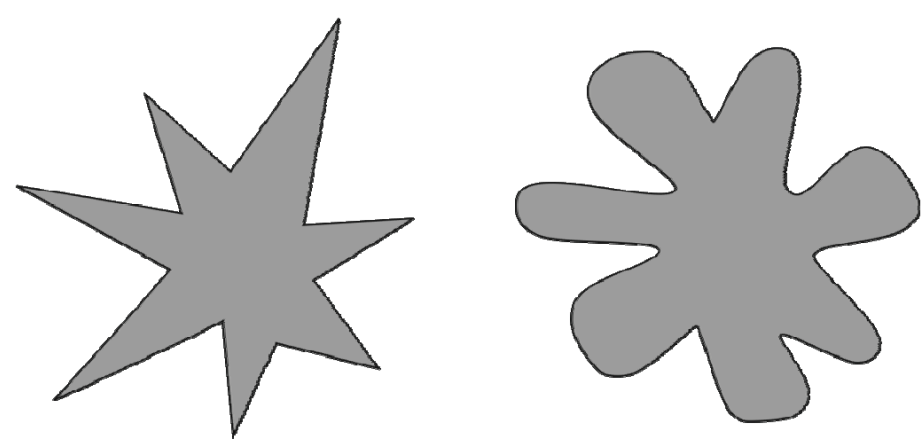

Another external evidence that intersubjectivity, the metaphorical nature of the language, and understanding others' bodily experience through our own are closely related can be autism. In autism neither of these seem to work properly. While autism is not a unitary condition and there are many kinds and gradations there are general characteristics such as detachment, lack of social skills, the absence of eye contact with others, lack of interest in or understanding of others' subjective worlds. These are also accompanied by difficulties in understanding metaphors:

"Thus, a subset of autistic children told to 'get a hold of themselves' or to 'get a grip' might start grasping at their own bodies. Much of language learning consists of 'taking a person's meaning' rather than taking them literally. Autistic children are often just not interested. Voices on the phone which ask, 'Are your parents in?' may be answered with a simple 'yes' or 'no' by an autistic child who would then hang up (FRANKS, 2010, p. 96)."

What is quite characteristics of autistic children is that they fail to develop a 'theory of other minds', an understanding that the others also experience the world as they do and that they also have their own subjective understanding of the world. Without this they are not able to do any 'mind-reading' of others, without this they are not interested to attempt to decode emotions on the face of others. The fact that autistic people have difficulties in understanding metaphors and take language quite literally also signifies that the neural

12 Adapted version of the bouba/kiki figures were retrieved at 18/08/2011 from: http://upload. wikimedia.org/wikipedia/en/thumb/e/e7/Booba-Kiki.svg/2000px-Booba-Kiki.svg.png 
infrastructure of empathy, shared meaning, intersubjectivity and metaphors are all related in our neural wiring.

\section{Concluding remarks - Possible convergences}

To conclude, it is worth reading about neuroscience for a sociologist especially in the presentation of a fellow social scientist. Franks selected the most important issues in current neuroscientific research which might be of interest to all those studying social and social-psychological issues. The result is a rich and detailed 'thick description' of social neuroscience and its implications to social science. This book is full of highly stimulating themes and accounts of research projects connecting two fields, which could not be more distant. Nonetheless, it also should be mentioned that my selection of topics here does not cover the entire scope of knowledge gathered and presented in the book about issues such as the new unconscious, determinism and free will, parts and dimensions of the selfhood, the role of emotion in decision-making. My selection was biased by my own interest or rather fascination but after reading the book I know that selective perception also has its biological foundations. I am sure that other readers will find the book compelling although not necessarily because of the aspects I highlighted in this review.

After giving the book its due acclaim, a few critical remarks might be made just to keep the balance (or maintain the image) of an objective reader. Firstly, in several paragraphs the text seems to be quite difficult to read since it is full of technical language like prefrontal cortex, angular gyrus, thalamus and amygdale. Although the author did introduce most of these concepts at some points, the frequent use could be overwhelming and the main argument seems to be lost in technical details sometimes. For sure, this is not a popular science book and Franks attempted to avoid 'sociological reductionism' of biological facts, yet, it came at a cost of a thicker text.

My second remark is that the main title (Neurosociology) implies a very broad and promising framework in which the research results of social neuroscience are interpreted in terms of social science. Franks stays in the paradigm of symbolic interactionism and mainly discusses Mead's ideas about gestures, action, perception and self. However, there are other social scientists who wrote extensively about the body as a social phenomenon - so it would be very interesting to see how Elias, Bourdieu, Foucault, Butler and other social scientists can be viewed and interpreted from the 'other side of the mirror'. 
Although, Douglas Massey, former president of the American Sociological Association, in the 2002 presidential address stated that neuroscience may be essential for contemporary sociology (Franks, 2010, p. 2), there are several reasons why the reader might have the suspicion that there will be no 'neuroscientific turn' (like the linguistic turn) in sociology as was one in cognitive psychology and in experimental economics resulting neuroeconomics. ${ }^{13}$ As Franks shows it in his book's introduction, the unit of analysis, the methodological approach, theory, tradition and practice are all fundamentally different in the case of sociology and neuroscience. Franks, however, sees an opportunity in combining these two distinctively different fields:

"But herein could lie an advantage and that is to break us out of our comfortable sociological 'assumptive order' and develop insights which may have otherwise been impossible, or at least very difficult to develop. In hypothesis testing, construct and convergent validity are the most highly regarded methods of privileging a thesis. If different methods and different theoretical positions converge on the same findings their validity is enhanced (FRANKS, 2010, p. 2)."

In my opinion, this is a little bit too modest as a program manifesto for a burgeoning new subfield of social science research. There must be other ways where sociology and neuroscience might converge apart from mutually reinforcing each other's theories in an extra-disciplinary way.

Before I started to write about Franks' book, one of my friends showed me an article published in Nature about schizophrenia and the city (LEDERBOGEN ET AL., 2011; KenNEDy \& AdolPhs, 2011). The article is about a research project which found that the longer one lived in big cities the higher the possibility is that his or her neural activity under stress condition will be similar to those who suffer from schizophrenia. In this project social and neuroscientists cooperated and in the future they want to enhance their model's reliability with further research involving social factors like subjective feeling of control, status and frequency of meeting with strangers. This is a good example where macrosociological factors are shown to have a strong influence on the workings of the mind. So, direct cooperation, building and testing theories together, in projects like this might be a possibility for the future of neurosociology.

Another field where neurosociology might be influential is the terrain of

13 To read more on neuroeconomics see:

http://neuroeconomics.typepad.com/neuroeconomics/2003/09/neuroeconomics_html [retireved 16/08/2011] 
action theories. Taking into consideration the constraints of rational choice theory, analytical sociology in its DBO (Desires-Beliefs-Opportunities) model already try to incorporate several other factors in actors' decisionmaking process like emotions, preferences and heuristics (Hedstrom, 2005). This as well as other ways of modeling social action and decision-making might benefit from reflecting on questions raised by topics such as the 'new' unconscious, determinism and free will, perception and the role of emotions in decision-making. As Franks' book shows these issues are at the forefront of research in neuroscience.

At a more philosophical level, social epistemology can also be the topic where there are meeting points between sociology and neuroscience. Franks refers to Lakoff and Johnson at several points of his book since they have already highlighted that the metaphorical nature of mind and of language has its roots in bodily experience and actions (LAKOFF \& JoHNSON, 1980). Using neuroscience's tools to understand in what way our categories of interpreting and perceiving the world are structured universally by the body and specifically by culture can be a research topic of pivotal importance for both disciplines.

All in all, I recommend this book to everyone who would like to know more about the biological foundations of our social nature. Whether this is a new step towards an interesting cooperation between equal partners or it is a just another, more subtle form of 'biological imperialism', is a question that the future will decide.

\section{BIBLIOGRAPHY}

Ariely, D. (2010) The Upside of Irrationality. New York: Harper Collins.

Ariely, D. (2008) Predictably Irrational. The Hidden Forces That Shape Our Decisions. New York: Harper Perennial.

Aronson, E. (2008) The social animal. New York \& Basingstoke, Worth Publishers Balogh, I. \& Karácsony, A. (2000) Német társadalomelméletek. Budapest: Balassi

Berger, P. L. \& Luckmann, T. (1966) The Social Construction of Reality: A Treatise in the Sociology of Knowledge. Garden City, NY: Anchor Books

Blackburn, s. (2009) Ethics: A very short introduction. Oxford: Oxford University Press.

Calhoun, C. J. \& Gerteis, J. \& Moody, J. \& Pffaf, S. \& Virk, I. (2007) Contemporary sociological theory. Malden\& Oxford \& Carlton: Blackwell

Christakis, N. A. \& Fowler, J. H. ([2009] 2010) Kapcsolatok hálójában. Budapest: Typotex 
Crossley, N. (2005) Sociology and the Body. In Calhoun, C \& Rojek, C. \& Turner, B. (eds.) The Sage Handbook of Sociology. pp. 442-455.

Dunbar, R. \& Shultz, S. (2007) Evolution in the social brain. Science 317 (5843) pp. 1344-1347.

Foucault, M. ([1969]1972): The Archaeology of Knowledge. London \& New York: Routledge.

Franks, D. D. (2010) Neurosociology. The Nexus between Neuroscience and Social Psychology. New York: Springer.

Hedstrom, P. (2005) Dissecting the Social. On the Principles of Analytical Sociology. Cambridge: Cambridge University Press

Kennedy, D. P. \& Adolphs, R. (2011) Stress and the city. Nature. 474. (23 June 2011) pp. 452-453.

Keysers, C. (web) Mirror neurons: a definition (Interview). retrieved at 15/08/2011 from: http://www.dnalc.org/view/1962-Mirror-neurons-a-definition.html

Lakatos, L. (2008) Biológiai imperializmus. In Némedi, D. (ed.) Modern Szociológiai Pradigmák. Budapest: Napvilág. pp. 157-202.

Lakoff, G. \& Johnson, M. (1980) Metaphors we live by. Chicago \& London: University of Chicago Press.

Lederbogen, F. et al. (2011) City living and urban upbringing affect neural social stress processing in humans. Nature. 474. (23 June 2011) pp. 498-501.

Pál, E. (2001) Néhány szempont a biológia és a szociológia közös történetének vizsgálatához. In Pál, E. (ed.) Útközben. Budapest: Új Mandátum. pp. 214-227.

Pál, E. (2004) Társadalmi evolúció és ‘organizmus' - avagy: mire jók a metaforák? In Gedeon, P. \& Pál, E. \& Somlai, P. (eds.) Az evolúció elméletei és metaforái a társadalomtudományokban. Budapest: Napvilág Kiadó. pp. 95-116.

Schutz, A. ([1932]1967) The phenomenology of the social world. Illinois: Northwestern University Press

Shilling, C. (2001) The Embodied Foundations of Social Theory. In Ritzer, G. \& Smart, B. (eds.) Handbook of Social Theory. Beverly Hills: Sage, pp. 439-457.

Society for Neuroscience [SfN] (2008) Brain briefings. 2008 November. retrieved at 15/08/2011 from: http://www.sfn.org/siteobjects/published/0000BDF20016F6 3800FD712C30FA42DD/299BC9518D9BED4789B6A3ABFBE5DFA4/file/BB_ mirror_neurons.pdf

Ramachandran, V.S. \& Hubbard, E. M. (2001) Synaesthesia-A Window Into Perception, Thought and Language. Journal of Consciousness Studies, 8 (12) pp. $3-34$.

Rogers, W. (2003) Social Psychology: Experimental and Critical Approaches. Maidenhead, Philadelphia: Open University Press.

Thaler r. H. \& Sunstein, C. R. (2008) Nudge: Improving Decisions About Health, Wealth, and Happiness. New York: Penguin. 